\title{
Serotonin and Drug-Induced Therapeutic Responses in Major Depression, Obsessive-Compulsive and Panic Disorders
}

Pierre Blier, M.D., Ph.D. and Claude de Montigny, M.D., Ph.D.

The therapeutic effectiveness of antidepressant drugs in major depression was discovered by pure serendipity. It took over 20 years before the neurobiological modifications that could mediate the antidepressive response were put into evidence. Indeed, whereas the immediate biochemical effects of these drugs had been well documented, their antidepressant action generally does not become apparent before 2 to 3 weeks of treatment. The different classes of antidepressant treatments were subsequently shown to enhance serotonin neurotransmission albeit via different pre-and postsynaptic mechanisms. Clinical trials based on this hypothesis led to the development of treatment strategies producing greater efficacy and more rapid onset of antidepressant action; that, is lithium addition and pindolol combination, respectively. It is expected that the better understanding recently obtained of the mechanism of action of certain antidepressant drugs in obsessive-compulsive and panic disorders will also lead to more effective treatment strategies for those disorders.

[Neuropsychopharmacology 21:91S-98S, 1999] (C) 1999 American College of Neuropsychopharmacology. Published by Elsevier Science Inc.
KEY WORDS: Antidepressant; Electroconvulsive shocks; Lithium; Pindolol; Hippocampus; Orbito-frontal cortex

In the late 1950s, the therapeutic effect of certain drugs in major depression was discovered by serendipity. An antidepressant response was observed in patients with tuberculosis taking iproniazide (Bloch et al. 1954), as well as in patients taking G22355, later named imipramine (Kuhn 1958). This discovery was a major breakthrough, because it allowed for treatment of depression on an outpatient basis. Until then, the only effective treatment modality for major depression was

From the Neurobiological Psychiatry Unit, Faculty of Medicine, McGill University, Montreal, Quebec, Canada.

Address correspondence to: P. Blier, M.D., Neurobiological Psychiatry Unit, Faculty of Medicine, McGill University, 1033 Pine Avenue West, Montreal, Quebec 43A 1A1, Canada.

Received October 30, 1998; revised February 19, 1999; accepted March 5, 1999. electroconvulsive shock treatment (ECT), which was generally given only to hospitalized patients.

It took several years after the demonstration of the antidepressant effect of iproniazide and imipramine to understand that these drugs could interfere with the catabolism of monoamines. The former drug was found to inhibit the oxidative degradation of serotonin (5-HT), noradrenaline (NE), and dopamine, and the latter agent to prevent the reuptake of 5-HT and NE back into the terminals responsible for their release in the extracellular space. Subsequently, multiple analogs of these two drugs were developed. However, neither the delay in onset of action, generally of 2 to 3 weeks, nor the efficacy, in about two-thirds of the patients, was improved. These features of the first generation of antidepressants were considerable drawbacks, given the elevated suicide risk of depressed patients (lifetime prevalence: 15$20 \%$ ) and the drugs' toxicity in overdose, notwithstanding their cumbersome side effects occurring from the very first day of treatment. 
The development of selective 5-HT reuptake inhibitors (SSRIs) constituted major progress, because they retain a good efficacy, they are not toxic in overdose, their side-effect profile is much more tolerable than that of tricyclic antidepressants (TCAs) or first-generation monoamine oxidase inhibitors (MAOIs), and their regimens seldom need to be titrated. Despite this improvement in the treatment of depression, important problems remained. In particular, the immediate biochemical effect of SSRIs stood in clear discordance with their delayed therapeutic onset of action, which is similar to that of tricyclics, and at least a third of the patients do not respond at all to these newer drugs. A reduction of the delay in onset of action and the problem of drug resistance could be solved only through better understanding of the basis for the antidepressant response.

\section{5-HT NEURON}

\section{POSTSYNAPTIC NEURON}

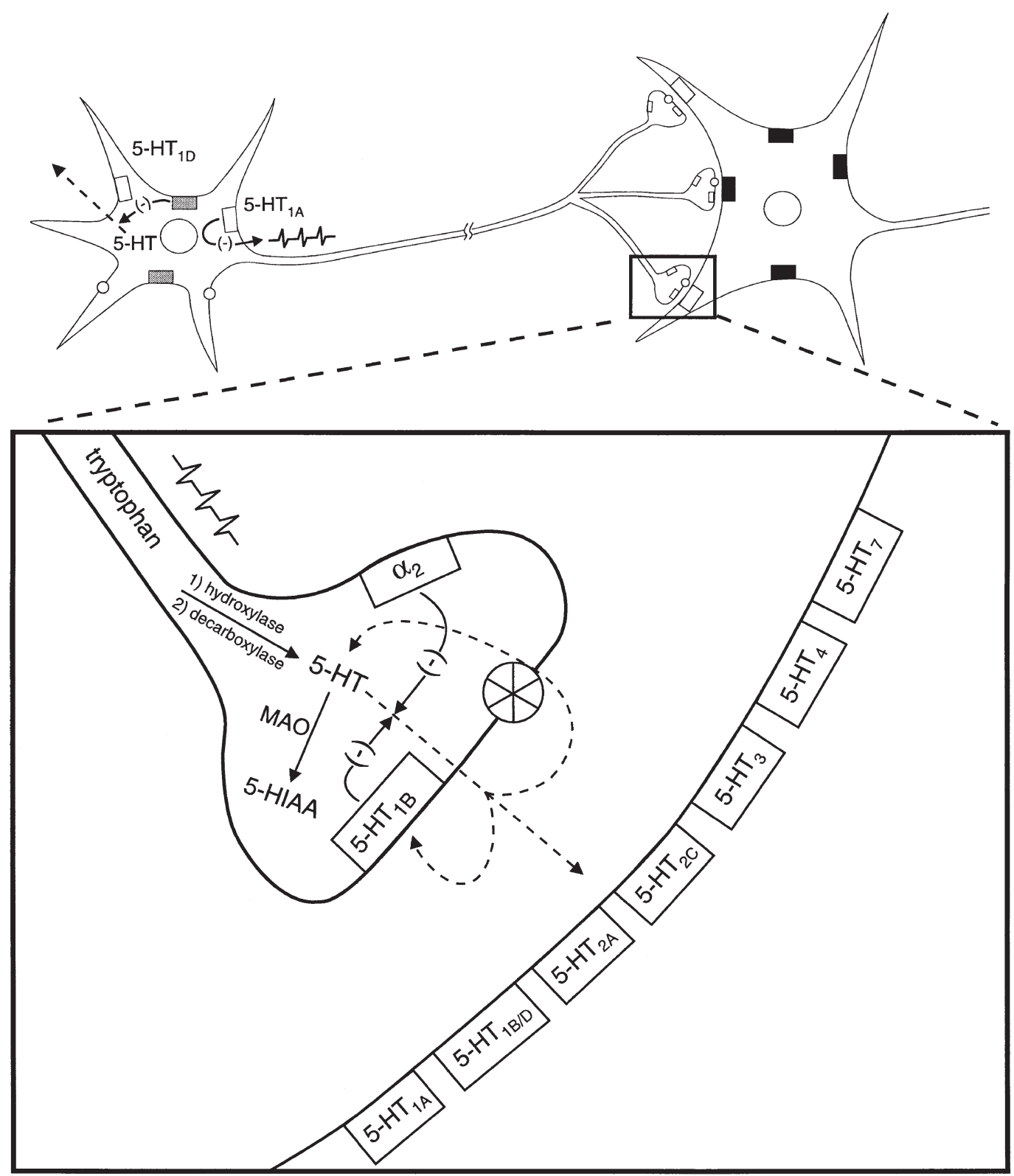

Figure 1. Presynaptic and postsynaptic factors regulating the effectiveness of serotonin (5-HT) neurotransmission. Only the subtypes of 5-HT receptors for which an electrophysiological response has been identified in unitary recordings are depicted. $5-\mathrm{HT}_{1 \mathrm{~A}}$ receptors on the cell body of 5-HT-containing neurons mediate an inhibitory effect on firing activity by the opening of potassium channels. $5-\mathrm{HT}_{1 \mathrm{D}}$ receptors on the cell body and $5-\mathrm{HT}_{1 \mathrm{~B}}$ receptors on the terminals exert an inhibitory action on 5-HT release. The hub on the 5-HT terminal represents the high-affinity reuptake carrier. The different symbols used to depict the postsynaptic 5-HT receptors is to indicate that they have different pharmacological properties. 


\section{EFFECTS OF ANTIDEPRESSANT TREATMENTS ON POSTSYNAPTIC 5-HT RECEPTORS}

Extensive electrophysiological investigations carried out in our laboratory have documented that several types of antidepressant treatments enhance 5-HT neurotransmission in the rat hippocampus (see Blier and de Montigny 1994). This net effect that is common to the major types of antidepressant treatments is, however, mediated via different mechanisms (see Figure 1, Table 1). All TCA drugs, independent of their capacity to inhibit the reuptake of 5-HT and/or NE, progressively enhance the responsiveness of postsynaptic $5-\mathrm{HT}_{1 \mathrm{~A}}$ receptors in the hippocampus. This sensitization, therefore, meets the criterion community of action, because all TCA drugs tested exert this effect. This phenomenon is not produced by the antipsychotic chlorpromazine nor by the anxiolytic diazepam, indicating that it is specific to the TCA family. Our group and other laboratories have indicated that this enhanced responsiveness to 5 -HT also occurs in other brain regions implicated in mediating depressive symptoms (i.e., the suprachiasmatic nucleus of the hypothalamus, the amygdala, the lateral geniculate body, and the facial motor nucleus). However, this sensitization to 5-HT by TCA drugs does not occur throughout the CNS (i.e., the somatosensory cortex). The sensitivity of 5-HT receptor subtypes other than that of the $5-\mathrm{HT}_{1 \mathrm{~A}}$ receptors may also be altered by TCA drugs. For example, in the facial motor nucleus, the receptors mediating the effect of 5-HT are of the $5-\mathrm{HT}_{2}$ subtype, and they are sensitized following repeated TCA drug administration (McCall and Aghajanian 1979; Menkes et al. 1980). The sensitization to 5-HT occurs with a time course (2-3 weeks) that is congruent with the delayed onset of action of these drugs in major depression (de Montigny and Aghajanian 1978).

Repeated, but not single, electroconvulsive shock administration also induces this sensitization to 5-HT in the dorsal hippocampus (de Montigny 1984; Chaput et al. 1991; Table 1). This is consistent with the clinical ef- fectiveness of repeated ECT sessions. Furthermore, it is not produced by repeated subconvulsive shocks, a mode of administration that does not produce a therapeutic response in humans.

To provide evidence that this sensitization to 5-HT could occur in humans and could account for the antidepressant effect of TCA drugs, an agent known to enhance 5-HT release was given to depressed patients treated with, but not responding to, TCA regimens. The hypothesis for this strategy was to release more 5-HT on already sensitized postsynaptic 5-HT receptors to obtain an additional enhancement of 5-HT neurotransmission. Since the initial report published in 1981 on the use of lithium addition, it has become widely recognized that this approach generally can produce a response within 2 weeks in about half the patients not responding to their antidepressant drug (de Montigny et al. 1981; Rouillon and Gorwood 1998). This potentiating effect of the antidepressant response by lithium, which was discovered through a rational research effort, allows most patients to be treated more rapidly than by substituting their antidepressant drug and as effectively as by carrying out a course of ECT (Dinan and Barry 1989).

\section{ENHANCEMENT OF THE FUNCTION OF 5-HT NEURONS BY ANTIDEPRESSANT DRUGS}

Monoamine oxidase (MAOI), selective serotonin reuptake (SSRI), and $5-\mathrm{HT}_{1 \mathrm{~A}}$ agonists, which have also been shown to be effective in major depression in placebo-controlled trials (see Robinson et al. 1990, Wilcox et al. 1996, and Stahl et al. 1998 for 5-HT 1 a agonists), all induce an initial attenuation of the firing activity of 5-HT neurons upon treatment initiation, because they increase the degree of activation of the somatodendritic $5-\mathrm{HT}_{1 \mathrm{~A}}$ autoreceptors controlling the firing rate of 5-HT neurons (Blier and de Montigny 1983, 1985, 1987). This attenuation of firing prevents an enhancement of 5-HT transmission, because the frequency of action potentials

Table 1. Effects of Long-Term Administration of Antidepressant Treatments on 5-HT Neurotransmission

\begin{tabular}{|c|c|c|c|c|c|}
\hline & $\begin{array}{l}\text { Responsiveness of } \\
\text { Somatodendritic } \\
\text { 5-HT } \mathrm{HT}_{1 \mathrm{~A}} \text { Autoreceptors }\end{array}$ & $\begin{array}{c}\text { Function of } \\
\text { Terminal } \\
5-\mathrm{HT}_{1 \mathrm{~B}} \\
\text { Autoreceptors }\end{array}$ & $\begin{array}{c}\text { Function of } \\
\text { Terminal } \\
\alpha_{2} \text {-Adrenergic } \\
\text { Heteroreceptors }\end{array}$ & $\begin{array}{c}\text { Responsiveness of } \\
\text { Postsynaptic } \\
\text { 5-HT }{ }_{1 \mathrm{~A}} \text { Receptors }\end{array}$ & $\begin{array}{c}\text { Net Effect } \\
\text { on 5-HT } \\
\text { Neurotransmission } \\
\end{array}$ \\
\hline SSRI & $\downarrow$ & $\downarrow$ & 0 & 0 & $\uparrow$ \\
\hline MAOI & $\downarrow$ & $\bigcirc$ & $\downarrow$ & $\bigcirc$ or $\downarrow$ & $\uparrow$ \\
\hline $5-\mathrm{HT}_{1 \mathrm{~A}}$ agonists & $\downarrow$ & $\bigcirc$ & ND & 0 & $\uparrow$ \\
\hline TCA & $\bigcirc$ & $\bigcirc$ & $\bigcirc$ or $\downarrow$ & $\uparrow$ & $\uparrow$ \\
\hline ECS & $\bigcirc$ & ○ & O & $\uparrow$ & $\uparrow$ \\
\hline Mirtazapine & $\bigcirc$ & $\bigcirc$ & $\downarrow$ & $\bigcirc$ & $\uparrow$ \\
\hline
\end{tabular}

The treatments were administered for a duration of 2 to 3 weeks, and the electrophysiological experiments were carried out in the rat dorsal raphe and $\mathrm{CA}_{3}$ region of the hippocampus. SSRI: selective serotonin reuptake inhibitors, MAOI: monoamine oxidase inhibitors, TCA: tricyclic antidepressants, ECT: electroconvulsive shocks. $\downarrow$ : decrease $\bigcirc$ : no change ND: not determined $\uparrow:$ increase. 
arriving at 5-HT terminals in postsynaptic structures determines in great part 5-HT release (Wilkinson et al. 1991). This is followed by a gradual recovery to normal firing activity of 5-HT neurons when the treatment is continued for 2 to 3 weeks because of a desensitization of the 5- $\mathrm{HT}_{1 \mathrm{~A}}$ autoreceptors. At this point, MAOIs enhance 5-HT transmission by increasing the amount of 5 -HT released per action potential as a result of a greater concentration of 5-HT in the terminals (Blier et al. 1986). SSRIs produce the same effect, not by augmenting the releasable pool of 5-HT as MAOIs do, but rather, by desensitizing the terminal 5-HT autoreceptor, which exerts a negative influence on the amount of 5-HT that is released per impulse (Chaput et al. 1986). $5-\mathrm{HT}_{1 \mathrm{~A}}$ agonists produce an enhanced tonic activation of postsynaptic $5-\mathrm{HT}_{1 \mathrm{~A}}$ receptors, as a result of a normalized firing activity of 5-HT neurons (and of 5-HT release as well) in the presence of the exogenous $5-\mathrm{HT}_{1 \mathrm{~A}}$ agonist acting on normosensitive postsynaptic $5-\mathrm{HT}_{1 \mathrm{~A}}$ receptors (Blier and de Montigny 1987).

To provide more definitive evidence that various types of antidepressant treatments enhance $5-\mathrm{HT}_{1 \mathrm{~A}}$ transmission in the forebrain, a new experimental paradigm was designed. It was reasoned that if such long- term treatments enhanced the tonic activation of inhibitory $5-\mathrm{HT}_{1 \mathrm{~A}}$ receptors in the hippocampus, then by blocking them in baseline conditions with a selective antagonist, a more pronounced increase in firing activity should be detectable. Such a greater disinhibition, when using WAY100-635, was observed in rats that received long-term treatment with a SSRI, a MAOI, a $5-\mathrm{HT}_{1 \mathrm{~A}}$ agonist, a dual 5-HT/NE reuptake blocker, mirtazapine, or ECT, but not with chlorpromazine, nor a single ECT (Haddjeri et al. 1998; Rueter et al. 1998).

An important line of evidence supporting the putative mechanism of action of SSRIs consists of the acceleration of their antidepressant effect with the $5-\mathrm{HT}_{1 \mathrm{~A}} /$ $\beta$-adrenergic antagonist pindolol (Artigas et al. 1994; Blier and Bergeron 1995). This approach is based on the capacity of pindolol to block the $5-\mathrm{HT}_{1 \mathrm{~A}}$ autoreceptor on the cell body of 5-HT neurons so as to prevent the initial decrease of the firing activity of these neurons at the beginning of the SSRI treatment. It is important to emphasize that pindolol does not block certain postsynaptic 5- $\mathrm{HT}_{1 \mathrm{~A}}$ receptors (Romero et al. 1996; Tada et al. 1999), otherwise the simultaneous blockade of both preand all postsynaptic $5-\mathrm{HT}_{1 \mathrm{~A}}$ receptors would not lead to a net increase in 5-HT neurotransmission via $5-\mathrm{HT}_{1 \mathrm{~A}}$ re-

\section{A. CONTROL Prior to}

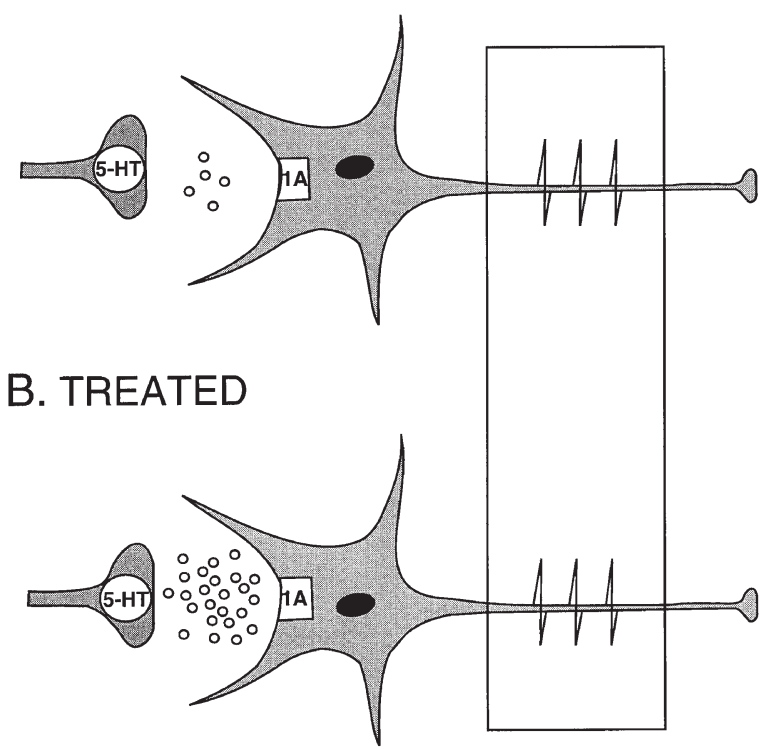

Following WAY 100635

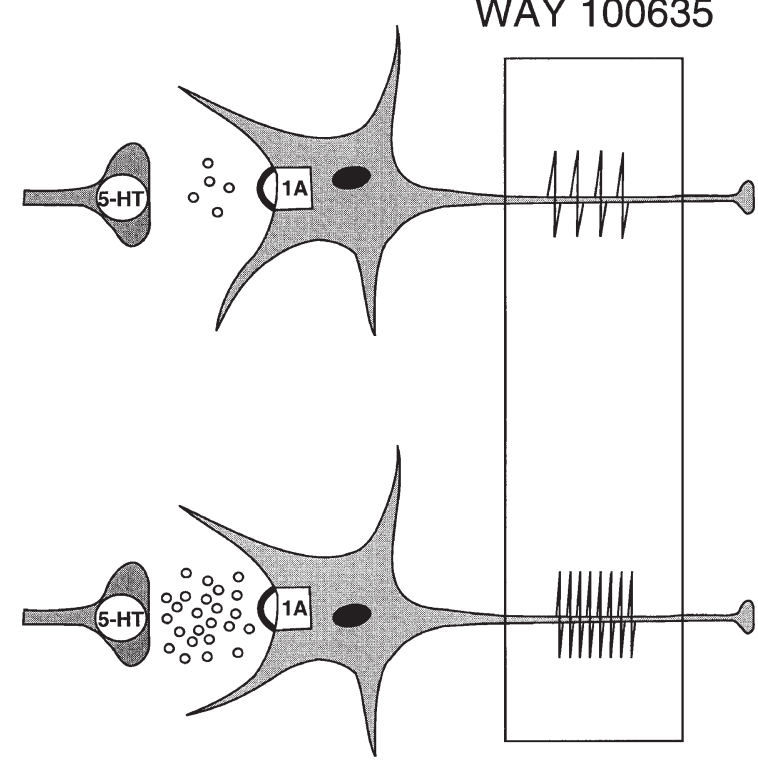

Figure 2. Diagrams illustrating the in vivo electrophysiological paradigm aimed at assessing the degree of tonic activation of postsynaptic $5-\mathrm{HT}_{1 \mathrm{~A}}$ receptors in the $\mathrm{CA}_{3}$ pyramidal neurons recorded in anesthetized rats. The hollow circles represent endogenous 5-HT being released from 5-HT terminals originating from the raphe nuclei. The firing activity of the pyramidal neurons illustrated within rectangles is determined by the investigator using a small activation current of quisqualate in the "prior to" condition, because these neurons hardly discharge under general chloral hydrate anesthesia. Following the intravenous injection of the selective 5- $\mathrm{HT}_{1 \mathrm{~A}}$ antagonist WAY 100, 635, illustrated by a semicircular bold line covering the 5-HT receptor, an increase in firing, resulting from the blockade of the inhibitory $5-\mathrm{HT}_{1 \mathrm{~A}}$ receptor, is produced in the presence of an enhanced 5-HT signal transfer through the 5- $\mathrm{HT}_{1 \mathrm{~A}}$ receptor. This enhanced transmission can occur via a greater synaptic amount of 5-HT, as depicted in the lower right diagram, or via sensitized postsynaptic 5- $\mathrm{HT}_{1 \mathrm{~A}}$ receptors as in the case following long-term administration of electroconvulsive shocks. 
ceptors, which are present in a particularly high density in the limbic system. Because 5-HT release in most postsynaptic regions is highly dependent on electrical impulse flow in 5-HT axons (Wilkinson et al. 1991), the prevention of the initial decrease of 5-HT neuronal firing activity by pindolol would physiologically mimic the desensitization of the $5-\mathrm{HT}_{1 \mathrm{~A}}$ autoreceptor, which has been documented to occur after a 2-week SSRI treatment. Five of six placebo-controlled trials indicate that pindolol combination with a SSRI from the beginning of the treatment does, in fact, accelerate the therapeutic effect of SSRIs in untreated depressed patients (Berman et al. 1997; Pérez et al. 1997; Tome et al. 1997; Bordet et al. 1998; Zanardi et al. 1997, 1998). In support of this hypothesis, the lack of an accelerating effect of pindolol addition to TCA drugs that do not block 5-HT reuptake, and consequently do not initially inhibit the firing rate of 5-HT neurons, can be mentioned (Blier et al. 1997). Furthermore, pilot trials indicate that pindolol also potentiates the antidepressant effect of the MAO-A inhibitor moclobemide and of the 5- $\mathrm{HT}_{1 \mathrm{~A}}$ agonist buspirone (Blier et al. 1997; Blier and Bergeron 1997). See Figure 2.

\section{SEROTONIN AND THE ANTI-OBSESSIONAL EFFECT OF SSSRIs}

Among all antidepressant treatments, including ECT, only the drugs that are potent 5 -HT reuptake blockers exert a clear therapeutic effect in obsessive-compulsive disorder (OCD) patients (Jenike 1993; Table 2). The first placebo-controlled trials of the TCA drug chlorimipramine (G34586), the only drug in this class with potent 5-HT reuptake blocking property, clearly demonstrated the effectiveness of this drug 13 years after the initial report of its effectiveness in this disorder (Fernandez and Lopez-Ibor 1967; Montgomery 1980). Subsequently, elegant cross-over studies with chlorimipramine and the selective NE reuptake blocker desipramine, which is also a TCA, have clearly shown that it is the capacity of the former drug to block the 5-HT reuptake process that is responsible for the anti-OCD effect (see Leonard et al. 1988). The advent of the newer nontricyclic 5-HT reuptake blockers truly established the pivotal role of the 5-HT system in the beneficial effect of certain antidepressant drugs. Because most of these drugs (fluoxetine, fluvoxamine, sertraline, paroxetine, citalopram) are from different chemical families, and the only common neurobiological property they share is their capacity to block the 5-HT reuptake process potently, this leaves little doubt that the anti-OCD effect of these drugs is mediated via the 5-HT system (Goodman et al. 1997).

The peculiar characteristic of SSRIs on the 5-HT system, as depicted in Table 1, is their capacity to desensitize terminal 5-HT autoreceptors. Such results were, however, obtained in the rat hippocampus and, subsequently, in the rat hypothalamus after 2- to 3-week treatments (Chaput et al. 1986; Moret and Briley 1990). It is, however, difficult to extrapolate such results to the treatment of OCD with SSRIs for two reasons. First, the optimal anti-OCD effect of SSRIs generally requires a much longer delay than the antidepressant effect (Montgomery 1994). Second, positron emission tomography (PET) scanning studies in humans have clearly delineated the orbitofrontal cortex-head of the caudate nucleus-thalamus neuronal circuitry as being involved in mediating OCD symptomatology (for a review, see Insel 1992), and not the hippocampus or the hypothalamus.

After a 3-week treatment with a SSRI, the electrically evoked release of $\left[{ }^{3} \mathrm{H}\right] 5-\mathrm{HT}$ is significantly enhanced in the hypothalamus, but not in the orbitofrontal cortex in guinea pig brain slices preloaded with $\left[{ }^{3} \mathrm{H}\right] 5-\mathrm{HT}$. After an 8-week treatment, however, the evoked release of $\left[{ }^{3} \mathrm{H}\right] 5-\mathrm{HT}$ is significantly enhanced in the orbitofrontal cortex. The concentration-effect curve using the 5-HT autoreceptor agonist 5-methoxytryptamine was shifted to the right in orbitofrontal, but not in dorsofrontal, cortex slices prepared from guinea pigs treated for 8 weeks with the SSRI paroxetine or fluoxetine (El Mansari et al. 1995; Bergqvist et al. 1999). These results indicate that

Table 2. Effectiveness of Antidepressant Treatments in Major Depression, Obsessive-Compulsive, and Panic Disorders

\begin{tabular}{lccc}
\hline & Depression & OCD & Panic Disorder \\
\hline Tricyclic antidepressant drugs & +++ & $0^{a}$ & +++ \\
Selective 5-HT reuptake inhibitors & +++ & ++ & +++ \\
Monoamine oxidase inhibitors & +++ & + & +++ \\
5-HT $_{1 \mathrm{~A}}$ agonists & ++ & 0 & 0 \\
Electroconvulsive shocks & +++ & 0 & ND \\
\hline
\end{tabular}

+++ : Produces a remission in at least half the patients; ++ : produces a partial response in about half of patients with obsessive-compulsive disorder or a remission in a significant percentage of depressed patients; +: may be useful in some cases; 0: no therapeutic benefit; ND: not determined.

${ }^{a}$ With the exception of chlorimipramine, which is the only tricyclic drug with a potent 5-HT reuptake blocking property. 
the enhanced 5-HT release observed in the orbitofrontal cortex could be attributed to a desensitization of the terminal 5-HT autoreceptor in that particular brain region.

Taken together, these data indicate that the enhanced 5-HT release in the orbitofrontal cortex, manifesting itself after a prolonged SSRI treatment, is fully consistent with the delayed onset of these drugs in OCD and, therefore, suggest that such a phenomenon could be the neurobiological substratum of the therapeutic effect of 5-HT reuptake inhibition in this disorder. This possibility is all the more likely, because the responsiveness to microiontophoretically applied 5-HT remains unaltered in the orbitofrontal cortex after an 8-week SSRI treatment (El Mansari and Blier 1997). Because, in the same experiments, the sensitivity to $5-\mathrm{HT}_{2}$ agonists was unaltered, whereas, that to the $5-\mathrm{HT}_{1 \mathrm{~A}}$ agonist $8-\mathrm{OH}-\mathrm{DPAT}$ was attenuated, it seems that an enhanced 5-HT release resulting from long-term SSRI administration increases $5-\mathrm{HT}$ transmission at postsynaptic $5-\mathrm{HT}_{2}$ receptors. These results imply that $5-\mathrm{HT}_{2}$ agonists that could selectively activate $5-\mathrm{HT}_{2}$ receptors on orbitofrontal cortex neurons would represent novel agents for the treatment of OCD that could be effective either in combination with SSRIs or possibly when used alone.

\section{SEROTONIN AND THE ANTIPANIC EFFECT OF SSRIs}

The first antidepressant drugs reported to be effective in this disorder were the TCA imipramine and a MAOI (Klein 1964; West and Dally 1959). Following the introduction of the SSRIs, it was observed that the latter drugs were also effective in the treatment of panic disorder. It is striking to observe clinically that at the beginning of the treatment, whether a TCA or a SSRI is used at the usual starting dose for depression, an exacerbation of the symptoms occurs, usually in the form of an increase in the number of spontaneous attacks. This problem does not arise as commonly when treating depression or OCD with the same drugs. Consequently, the starting dose is decreased by at least half to avoid this exacerbation and is then increased progressively to the therapeutic range used in depression. This difference between depressed patients and those suffering from panic disorder clearly delineates a hypersensitivity of 5-HT and/or NE receptors in the latter patients. Subsequently, the therapeutic effects of the drugs occur gradually at about the same rate as in the treatment of major depression. Typically, after about 6 weeks of treatment, spontaneous panic attacks rarely occur. This observation suggests that similar adaptive changes that mediate the antidepressant response may also account for the antipanic action of these drugs. However, not all drugs effective in the treatment of depression are also useful in panic disorder. For example, $5-\mathrm{HT}_{1 \mathrm{~A}}$ agonists, which are endowed with antidepressant properties when given at adequate doses for a sufficient time, have, thus far, not been found of therapeutic value in panic disorder (Table 2). The latter clinical observation suggests that postsynaptic 5-HT receptors other than those of the $5-\mathrm{HT}_{1 \mathrm{~A}}$ subtype are responsible for the antipanic effect of SSRIs, TCAs, and MAOIs. Obviously, the changes responsible for the antipanic effect may also occur in brain areas different from those responsible for the antidepressant action. For example, at a structural level, PET scan studies have consistently identified abnormalities in the parahippocampal region in panic disorder patients (see Baxter 1995). At a neurochemical level, it is interesting to note that the shortest active form of cholecystokinin, a four-amino acid peptide, when injected intravenously in human subjects, immediately triggers a classical panic attack (de Montigny 1989; Bradwejn et al. 1991). However, cholecystokinin terminals in the brain are endowed with $5-\mathrm{HT}_{3}$ receptors, and a subpopulation of $5-\mathrm{HT}_{3}$ receptors was reported to be desensitized following long-term administration of a SSRI (Paudice and Raiteri 1991; Blier and Bouchard 1994). Interestingly, the panicogenic response to cholecystokinin is markedly attenuated following long-term treatment with the TCA imipramine or the SSRI fluvoxamine (Bradwejn and Koszycki 1994; van Megen et al. 1996).

Another mechanism by which SSRIs could exert, at least in part, their antipanic effect is by an attenuation of the efficacy of NE neurotransmission. Indeed, it is generally recognized that panic disorder patients have an increased NE activity, and the $\alpha_{2}$-adrenoceptor antagonist yohimbine can trigger panic attacks in these individuals (Charney et al. 1984). It was recently observed that long-term, but not acute or subacute, administration of SSRIs decreases the firing activity of locus coeruleus NE neurons (Béïque et al. 1998; Szabo et al. 1999). Because the time course of this effect of SSRIs is fully consistent with their onset of action on panic attacks, it is possible that the gradual enhancement of the inhibitory influence of 5-HT on locus coeruleus neurons does contribute to their therapeutic effect in panic disorder.

\section{CONCLUSION}

In the late 1960s, it was proposed that the 5-HT system may play a major role in both the etiopathology and the therapeutics of major depression (Coppen 1967). Major breakthroughs were made in the therapeutics of major depression based on a better knowledge of the physiology of the 5-HT system. Furthermore, the observation that SSRIs were effective in several other psychiatric disorders served as an additional incentive to pursue the study of the heterogeneity of 5-HT receptors in different brain structures and their relationship with other 
chemospecific systems. Such research endeavors should continue to generate new therapeutic approaches for various psychiatric disorders.

\section{REFERENCES}

Artigas F, Perez V, Alvarez E (1994): Pindolol induces a rapid improvement of depressed patients with serotonin reuptake inhibitors. Arch Gen Psychiat 51:248-251

Baxter LR Jr (1995): Neuroimaging studies of human anxiety disorders. In Bloom FE, Kupfer D (eds), Psychopharmacology: The Fourth Generation of Progress. New York, Raven, pp 1287-1300

Béïque J-C, de Montigny C, Blier P, Debonnel, G (1998): Blockade of the 5-hydroxytryptamine and norepinephrine uptake by venlafaxine: Comparative study with paroxetine and desipramine. Brit J Pharmacol 125:526-532

Bergqvist PBF, Bouchard C, Blier P (1999): Effect of longterm administration of antidepressant treatments on serotonin release in brain regions involved in obsessivecompulsive disorder. Biol Psychiat 45:164-174

Berman RM, Darnell AM, Miller HL, Anand A, Charney DS (1997): Effect of pindolol in hastening response to fluoxetine in the treatment of major depression: A doubleblind, placebo-controlled trial. Am J Psychiat 154:37-43

Blier P, Bergeron R (1995): Effectiveness of pindolol with selected antidepressant drugs in the treatment of major depression. J Clin Psychopharmacol 15:217-222

Blier P and Bergeron, R (1997): Early onset of therapeutic action in depression and greater efficacy of antidepressant treatments: Are they related? Int Clin Psychopharmacol 12:21-28

Blier P, Bouchard C (1994): Modulation of 5-HT release in the guinea pig brain following long-term administration of antidepressant drugs. Br J Pharmacol 113:485-495

Blier P, de Montigny C (1983): Electrophysiological studies on the effect of repeated zimelidine administration on serotonergic neurotransmission in the rat. J Neurosci 3:1270-1278

Blier P, de Montigny C (1985): Serotonergic but not noradrenergic neurons in rat CNS adapt to long-term treatment with monoamine oxidase inhibitors. Neuroscience 16:949-955

Blier P, de Montigny C (1987): Modifications of 5-HT neuron properties by sustained administration of the $5-\mathrm{HT}_{1 \mathrm{~A}}$ agonist gepirone: Electrophysiological studies in the rat brain. Synapse 1:470-480

Blier P, de Montigny C (1994): Current advances and trends in the treatment of depression. Trends Pharmacol Sci 15:220-226

Blier P, de Montigny C, Azzaro AJ (1986): Modification of serotonergic and noradrenergic neurotransmission by repeated administration of monoamine oxidase inhibitors: Electrophysiological studies in the rat CNS. J Pharmacol Exp Ther 227:987-994

Blier P, Bergeron R, de Montigny C (1997): Selective activation of postsynaptic $5-\mathrm{HT}_{1 \mathrm{~A}}$ receptors produces a rapid antidepressant response. Neuropsychopharmacology 16:333-338
Bloch RG, Dooneief AS, Buchberg AS, Spellman S (1954): The clinical effect of isoniazid and iproniazid in the treatment of pulmonary tuberculosis. Ann Int Med 40:881-900

Bordet R, Thomas P, Dupuis B (1998): Effect of pindolol on onset of action of paroxetine in the treatment of major depression: Intermediate analysis of a double-blind, placebo-controlled trial. Am J Psychiat 155:1346-1351

Bradwejn J, Koszycki D, Shriqui C (1991): Enhanced sensitivity to cholecystokinin tetrapeptide in panic disorder. Arch Gen Psychiat 48:603-610

Bradwejn J, Koszycki D (1994): Imipramine antagonism of the panicogenic effects of cholecystokinin tetrapeptide in panic disorder patients. Am J Psychiat 151:261-263

Chaput Y, de Montigny C, Blier P (1986): Effect of a selective 5-HT reuptake blocker, citalopram, on the sensitivity of 5-HT autoreceptors: Electrophysiological studies in the rat. Naunyn-Schmiedeberg's Arch Pharmacol 333:342348

Chaput Y, de Montigny C, Blier P (1991): Presynaptic and postsynaptic modifications of the serotonin system by long-term antidepressant treatments: Electrophysiological studies in the rat brain. Neuropsychopharmacology 5:219-229

Charney DS, Heninger GR, Breier A (1984): Noradrenergic function in panic anxiety: Effects of yohimbine in healthy subjects and patients with agoraphobia and panic disorder. Arch Gen Psychiat 43:1155-1161

Coppen A (1967): The biochemistry of affective disorders. Brit J Psychiat 113:1237-1264

de Montigny C (1984): Electroconvulsive treatments enhance responsiveness of forebrain neurons to serotonin. J Pharmacol Exp Ther 228:230-234

de Montigny C (1989): Cholecystokinin tetrapeptide induces panic-like attacks in healthy volunteers: Preliminary findings. Arch Gen Psychiat 46:511-517

de Montigny C and Aghajanian GK (1978): Tricyclic antidepressants: Long-term treatment increases responsivity of rat forebrain neurons to serotonin. Science 202:1303-1306

de Montigny C, Grunberg F, Mayer A, Deschenes JP (1981): Lithium induces rapid relief of depression in tricyclic antidepressant drug nonresponders. $\mathrm{Br} \mathrm{J}$ Psychiat 138:252-256

Dinan TG, Barry S (1989): A comparison of electroconvulsive therapy with a combined lithium and tricyclic combination among depressed tricyclic nonresponders. Acta Psychiatr Scand 80:97-100

El Mansari M, Bouchard C, Blier P (1995): Alteration of serotonin release in the guinea pig orbitofrontal cortex: relevance to the treatment of obsessive compulsive disorder. Neuropsychopharmacology 13:117-127

El Mansari M, Blier P (1997): Effect of a prolonged paroxetine treatment on the responsiveness of postsynaptic 5-HT receptors in the rat orbitofrontal cortex. Neurosci (Abst) 23:974

Fernandez CE, Lopez-Ibor JJ (1967): Monochlorimipramine in the treatment of psychiatric patients resistant to other therapies. Actas Luso Esp Neurol Psiquiatr Cienc 26:119

Goodman WK, Ward H, Kablinger A, Murphy T (1997): Fluvoxamine in the treatment of obsessive-compulsive disorder and related conditions. J Clin Psychiat 58:32-49 
Haddjeri N, Blier P, de Montigny C (1998): Long-term antidepressant treatments result in a tonic activation of forebrain 5- $\mathrm{HT}_{1 \mathrm{~A}}$ receptors. J Neurosci 18:10150-10156

Insel TR (1992): Toward a neuroanatomy of obsessive-compulsive disorder. Arch Gen Psychiat 49:739-744

Jenike MA (1993): Obsessive-compulsive disorder: Efficacy of specific treatments as assessed by controlled trials. Psychopharmacol Bull 29:487-499

Klein DF (1964): Delineation of two drug-response anxiety syndromes. Psychopharmacologia 5:397-408

Kuhn R (1958): The treatment of depressive states with G22355 (imipramine hydrochloride). Am J Psychiat 115:459-464

Leonard HL, Swedo S, Rapoport JL, Coffey M, Cheslow D (1988): Treatment of childhood obsessive compulsive disorder with clomipramine and desmethylimipramine: A double-blind cross-over comparison. Psychopharmacol Bull 24:93-95

McCall RB and Aghajanian GK (1979): Serotonergic facilitation of facial motoneuron excitation. Brain Res 169:11-27

Menkes DB, Aghajanian GK, McCall RB (1980): Chronic antidepressant treatment enhances $\alpha$-adrenergic and serotonergic responses in the facial nucleus. Life Sci 27:45-55

Montgomery SA (1980): Clomipramine in obsessional neurosis: A placebo- controlled trial. Pharm Med 1:189-192

Montgomery SA (1994): Pharmacological treatment of obsessive-compulsive disorder. In Hollander E, Zohar J, Marazziti D, Olivier B (eds), Current Insights in Obsessive Disorder. New York, Wiley, pp 215-226

Moret C, Briley M (1990): Serotonin autoreceptor subsensitivity and antidepressant activity. Eur J Pharmacol 180:351-356

Paudice P, Raiteri M (1991): Cholecystokinin release mediated by $5-\mathrm{HT}_{3}$ receptors in rat cerebral cortex and nucleus accumbens. Br J Pharmacol 103:1790-1794

Pérez V, Gilaberte I, Faries D, Alvarez E, Artigas F (1997): Randomised, double-blind, placebo-controlled trial of pindolol in combination with fluoxetine antidepressant treatment. Lancet 349:1594-1597

Robinson DS, Rickels K, Feighner J, Fabre Jr LF, Gammans RE, Shrotriya RC, Alms DR, Andary JJ, Messina ME (1990): Clinical effects of the $5-\mathrm{HT}_{1 \mathrm{~A}}$ partial agonists in depression: A composite analysis of buspirone in the treatment of depression. J Clin Psychopharmacol 10:67S-76S

Romero L, Bel N, Artigas F, de Montigny C, Blier P (1996): Effect of pindolol at pre- and postsynaptic 5-HT1A receptors: In vivo microdialysis electrophysiological studies in the rat brain. Neuropsychopharmacol 15:349-360
Rouillon F, Gorwood P (1998): The use of lithium to augment antidepressant medication. J Clin Psychiat 59:32-41

Rueter L, de Montigny C, Blier P (1998): Electrophysiological characterization of the effect of long-term duloxetine administration on the rat serotonergic and noradrenergic systems. J Pharmacol Exp Ther 285:404-412

Stahl SM, Kaiser L, Roeschen J, Keppel Hesselink JM, Orazem J (1998): Effectiveness of ipsapirone, a 5-HT-1A partial agonist, in major depressive disorder: Support for the role of 5-HT-1A receptors in the mechanism of action of serotonergic antidepressants. Int J Neuropsychopharmacol 1:11-18

Szabo ST, de Montigny C, Blier P (1999): Long-term treatment with paroxetine decreases the firing activity of locus coeruleus noradrenergic neurons. Brit J Pharmacol 126:568-571

Tada K, Kasamo K, Ueda N, Suzuki T, Kojima T, Ishikawa K (1999): Anxiolytic 5-hydroxytryptamine ${ }_{1 \mathrm{~A}}$ agonists suppress firing activity of dorsal hippocampus CA1 pyramidal neurons through a postsynaptic mechanism: Single-unit study in unanesthetized, unrestrained rats. J Pharmacol Exp Ther 288:843-848

Tome MB, Isaac MT, Harte R, Holl C (1997): Paroxetine pindolol: A randomized trial of serotonergic autoreceptor blockade in the reduction of antidepressant latency. Int Clin Psychopharmacol 12:81-89

van Megen HJGM, Westenberg HGM, den Boer JA, Kahn RS (1996): Cholecystokinin in anxiety. Eur Neuropsychopharmacol 6:263-280

West ED, Dally PJ (1959): Effects of iproniazid in depressive syndromes. Br Med J 5163:1491-1494

Wilkinson LO, Auerbach SB, Jacobs BL (1991): Extracellular serotonin levels change with behavioral state but not pyrogen-induced hyperthermia. J Neurosci 11:27322741

Wilcox CS, Ferguson JM, Dale JL, Heiser JF (1996): A doubleblind trial of low- and high-dose ranges of gepirone-ER compared with placebo in the treatment of depressed outpatients. Psychopharmacol Bull 32:335-342

Zanardi R, Artigas F, Sforzini L, Gasperini M, Smeraldi E, Perez J (1997): How long pindolol should be associated to paroxetine to improve the antidepressant response. J Clin Psychopharmacol 17:446-450

Zanardi R, Franchini L, Gasperini M, Lucca A, Smeraldi E, Pérez J (1998): Faster onset of fluvoxamine in combination with pindolol in the treatment of delusional depression: A controlled study. J Clin Psychopharmacol $18: 441-446$ 